\title{
Quasi-Rheotaxy a new technique to grow large grain thin films on low cost amorphous substrates $(*)$
}

\author{
N. Romeo, V. Canevari, G. Sberveglieri, A. Tosi and A. Camanzi $\left({ }^{* *}\right)$ \\ CNR, GNSM and PFE-SPES, Istituto di Fisica dell'Università, Parma, Italy.
}

(Reçu le 10 juin 1980, révisé le $1^{\mathrm{er}}$ octobre 1980, accepté le 6 octobre 1980)

\begin{abstract}
Résumé. - Nous avons développé une nouvelle technique pour faire croître des couches minces avec des cristaux très larges. Cette technique, que nous avons appelée Quasi-réotaxie, consiste à déposer des couches minces sur un substrat qui est porté à une température voisine de son point de fusion. Nous avons préparé par Quasi-réotaxie plusieurs semiconducteurs qui sont considérés comme prometteurs pour la conversion solaire photovoltaïque, tels que CdS, CdTe et $\mathrm{CuGaInSe}_{2}$. Nous avons employé comme substrats presque fondus des éléments métalliques à basse température de fusion et à basse tension de vapeur c'est-à-dire $\mathrm{Sn}, \mathrm{Pb}, \mathrm{Bi}$ et $\mathrm{Tl}$. Nous avons employé l'acier inoxydable comme substrat de base pour supporter les couches minces des éléments presque fondus, évaporés dans le même système d'évaporation que celui utilisé pour les couches minces de semiconducteurs. Des cristaux de large dimension jusqu'à $10 \mu \mathrm{m}$ ont été obtenus dans des couches minces qui ont été préparées par Quasi-réotaxie. Les couches minces de cristaux de large dimension pourraient être employées pour préparer des cellules solaires de bas coût puisqu'elles ont été préparées sur un substrat de bas coût.
\end{abstract}

\begin{abstract}
A new technique of growing large crystalline grain thin films has been developed. This method, that we called Quasi-Rheotaxy, consists in the deposition of thin films on substrates kept at a temperature near their melting point. Several semiconductor thin films which are considered as promising materials for solar photovoltaic conversion such as $\mathrm{CdS}, \mathrm{CdTe}$ and $\mathrm{CuGaInSe}_{2}$ have been grown by Quasi-Rheotaxy. Low melting point and low vapour pressure metallic elements, such as $\mathrm{Sn}, \mathrm{Pb}, \mathrm{Bi}$ and $\mathrm{Tl}$, have been used as quasi-melted substrates. Stainless steel was used as a base substrate to support the thin layer of the quasi-melted elements which were evaporated in the same vacuum system in which the semiconductor films were prepared. Large crystalline and columnar grains with a size up to $10 \mu \mathrm{m}$ have been obtained in films grown by Quasi-Rheotaxy. The large crystalline grain thin films, since they are grown on low cost substrates, could be used to build low cost thin film solar cells.
\end{abstract}

1. Introduction. - Low cost high efficiency thin film photovoltaic devices could be realized, if large crystalline grain thin films of photovoltaic materials would be obtained on amorphous low cost substrates. Unfortunately, when thin films are grown on amorphous substrates, their crystalline grain size is generally much less than $1 \mu \mathrm{m}$, while the smallest grain dimension which is required in thin film direct gap absorbers solar cells to overcome the fficiency value of $10 \%$ is about $2 \mu \mathrm{m}$ or greater [1,2]. For example, Hovel [1], by considering a minority carrier diffusion length comparable with the grain size, reports that a thin film solar cell based on GaAs with a resistivity of $10^{-2} \Omega . \mathrm{cm}$ could exhibit a conversion efficiency greater than $18 \%$ when the thin film grain size is

(*) Communication présentée à la réunion annuelle du Groupe Français de Croissance Cristalline et Colloque Epitaxie, Marseille, 19-21 mai 1980.

(**) Assoreni, Monterotondo, Roma, Italy. about $1 \mu \mathrm{m}$. But, Soclof and Iles, by considering the more realistic case of a minority carrier diffusion length 5 times lower than the grain size, find a conversion efficiency aroung $10 \%$. In practical cases, one can expect a conversion efficiency between 10 and $18 \%$ for a thin film solar cell in which the grain size is $1 \mu \mathrm{m}$.

Recently, it was suggested [3] that the use of Rheotaxy would give the possibility of growing large grain thin films on low cost substrates. Rheotaxy, which means growth on liquid substrates, was already successfully used to grow $\mathrm{Si}$ films on liquid tin kept at a temperature of $1100-1250^{\circ} \mathrm{C}$ [4]. Grain sizes up to $100 \mu \mathrm{m}$ have been obtained by using the chemical vapour deposition technique to transport $\mathrm{Si}$ on melted tin [4].

We tried to apply rheotaxy to the growth of thin films of some compound semiconductors which are considered as promising materials for photovoltaic applications, such as $\mathrm{CdS}$ and ternary chalcopyrite $\mathrm{CuInSe}_{2}$ and $\mathrm{CuGaSe}_{2}$. By using evaporation techni- 
ques such as the multisource-evaporation and the flash-evaporation, we deposited the above materials on a thin film of liquid Sn or In previously evaporated on mica or $\mathrm{W}$ in the same vacuum system. A temperature of $250^{\circ} \mathrm{C}$, which is higher than the melting point of both In and Sn, was used for the substrates [5]. Notwithstanding the fact that an increase of one order of magnitude in the grain size was obtained when the deposition was made on the liquid substrates, a very disuniform distribution of the grains together with a non complete covering of the liquid metal by the deposited films was observed. This was attributed to the fact that the liquid metal tends to form droplets on the substrate due to its high surface tension.

To avoid the droplets formation, we tried to grow the semiconductor films on metals kept at a temperature lower than their melting point. Unexpectedly, it was observed that the films grew with very large and uniformly distributed grains also at temperatures $30-40^{\circ} \mathrm{C}$ lower then the melting point of the underlying metals. On the analogy of the Rheotaxy, we called this new method of growing large grain thin films on quasi-liquid substrates Quasi-Rheotaxy.

2. Experimental results. - By using Quasi-Rheotaxy, we prepared thin films of $\mathrm{CdS}, \mathrm{CdTe}$ and $\mathrm{CuGa}_{0.5} \operatorname{In}_{0.5} \mathrm{Se}_{2}$. As a base substrate, polished stainless steel was used. CdS and CdTe were prepared by the multisource evaporation method [6], while $\mathrm{CuGa}_{0.5} \mathrm{In}_{0.5} \mathrm{Se}_{2}$ was prepared by flash-evaporation [7]. As quasi-liquid substrates, some low vapour pressure metals whose melting points are in the range between 200 and $350^{\circ} \mathrm{C}$ were chosen. These are : $\mathrm{Sn}, \mathrm{Bi}$ and $\mathrm{Pb}$ whose melting points are respectively : $232^{\circ} \mathrm{C}$, $271^{\circ} \mathrm{C}$ and $327^{\circ} \mathrm{C}$. CdS was deposited on Sn, CdTe on $\mathrm{Bi}$ and $\mathrm{Pb}$ and $\mathrm{CuGa}_{0.5} \mathrm{In}_{0.5} \mathrm{Se}_{2}$ on $\mathrm{Bi}$. The preparation of the films was made in the following way. First of all, a $2 \mu \mathrm{m}$ thick film of the metal which was used as a quasi-liquid substrate was evaporated on half a part of the stainless steel base substrate, by using a suitable mask. Then, the semiconductor film was deposited on all the substrate. In such a way, it was possible to obtain at the same time the deposition of the semiconductor film on the stainless steel substrate and on the quasi-liquid substrate. Therefore, a direct comparison of the structural properties of the two parts of the film was possible. The semiconductor films were prepared at various temperatures of the substrate, from a value $40^{\circ} \mathrm{C}$ lower than the melting point of the metal substrate up to the melting point of the metal substrate. In all cases, a grain size from one to two orders of magnitude larger in the films grown on quasi-liquid substrates than the grain size obtained in the films grown directly on stainless steel was observed. The grain size increased by increasing the substrate temperature towards the melting point of the quasi-liquid substrates. However, by approaching the melting point of the metals which were used as substrates, a separation of the grains was observed in some cases. Some experimental results are shown
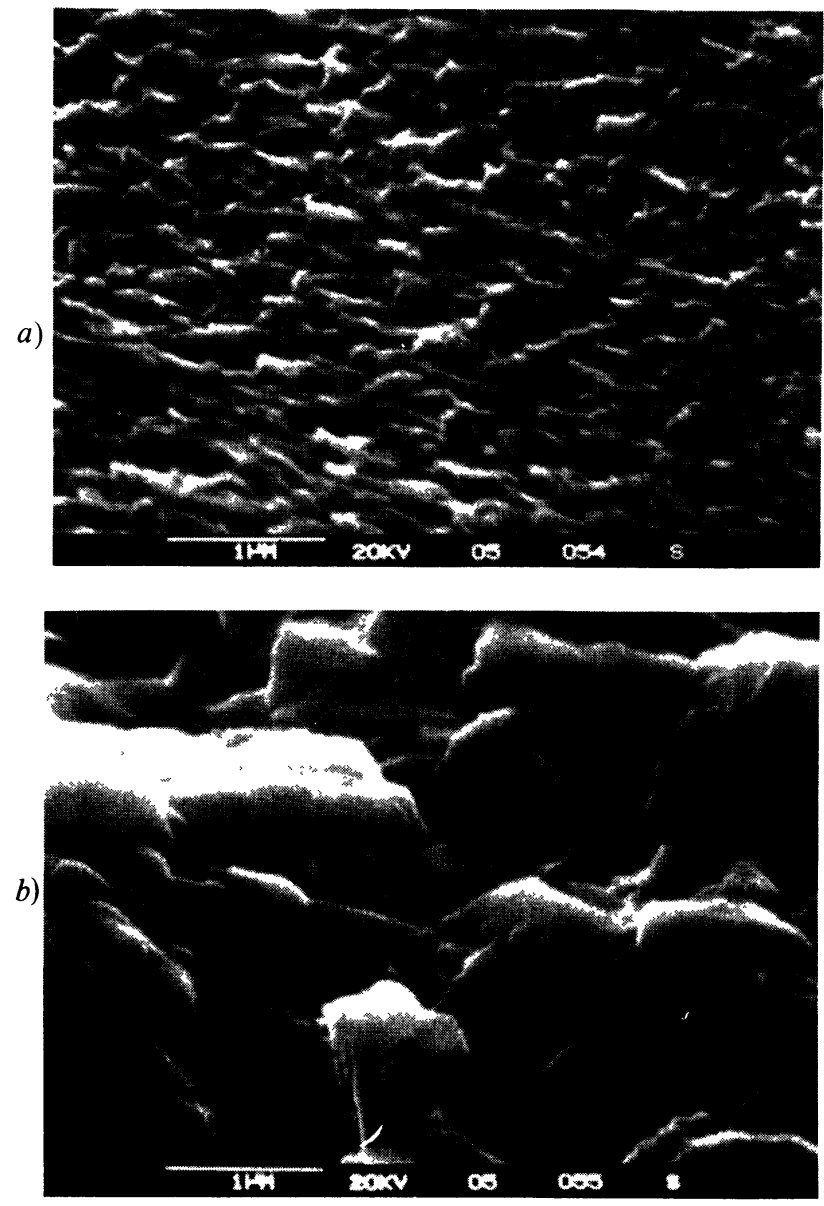

Fig. $1 a$ and $b$. - Figure $1 a$ is a S.E.M. micrograph of a CdS film deposited at $212^{\circ} \mathrm{C}$ directly on stainless steel. The thickness of the $\mathrm{CdS}$ film is about $6 \mu \mathrm{m}$. Figure $1 b$ is a S.E.M. micrograph of a CdS film deposited contemporaneously to the film of figure $1 a$ on a $2 \mu \mathrm{m}$ thick film of $\mathrm{Sn}$ previously evaporated on stainless steel.

in the figures 1, 2, 3, 4 which are micrographs obtained by a scanning electron microscope. Figure 1 shows a film of CdS grown at $212^{\circ} \mathrm{C}$. Figure $1 a$ represents a CdS film grown directly on stainless steel, while figure $1 b$ represents a $\mathrm{CdS}$ film grown in the same conditions, in which the film shown in figure $1 a$ was prepared, but on a $2 \mu \mathrm{m}$ thick layer of Sn. As one can see, the film grown on Sn displays a grain size of about one order of magnitude larger in respect to that deposited on steel. In figure 2 one can observe the columnar growth of $\mathrm{CdS}$ on the underlying $\mathrm{Sn}$ film. Figure 3 show a thin film of CdTe grown on $\mathrm{Bi}$ at a temperature of about $250^{\circ} \mathrm{C}$. The grain size is about 4-6 $\mu \mathrm{m}$. At last, figure 4 represents a film of $\mathrm{CuGa}_{0.5} \mathrm{In}_{0.5} \mathrm{Se}_{2}$ grown on $\mathrm{Bi}$ at $250^{\circ} \mathrm{C}$. In this case, the grain size approaches $10 \mu \mathrm{m}$. Due to the fact that the semiconducting film were deposited on a metallic substrate, it was impossible to measure their mobility by Hall effect. We only measured the resistivity of the films deposited on metallic quasi-melted substrate and we compared this resistivity with that of the films deposited on metallic solid substrate in the same conditions. We found that the resistivity of the film 


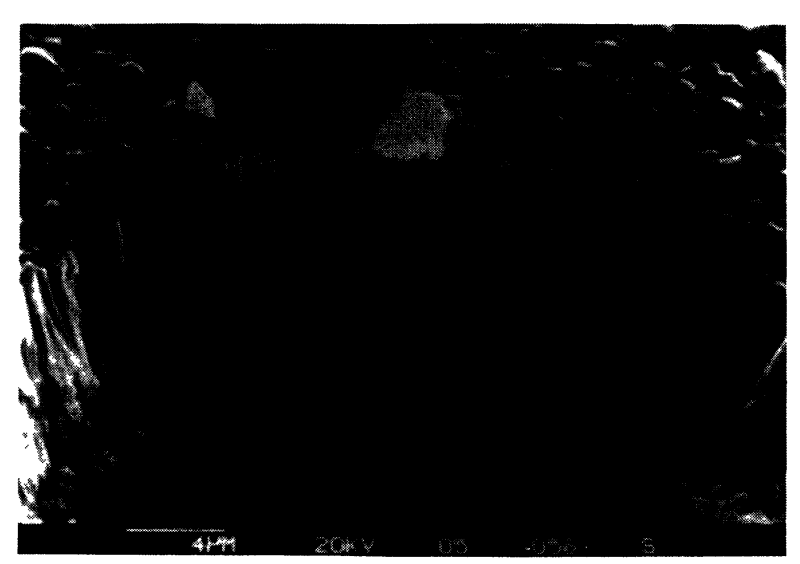

Fig. 2. - A lateral view of the CdS film shown in figure $1 b$. It is possible to see the columnar growth of the CdS film on the underlying film of Sn.

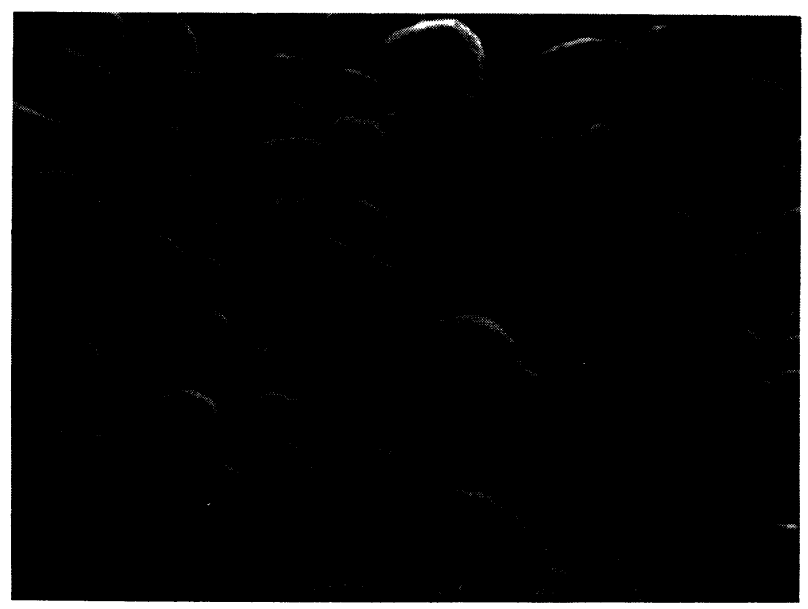

Fig. 3. - S.E.M. micrograph of a $4 \mu \mathrm{m}$ thick CdTe film grown at $250^{\circ} \mathrm{C}$ on a $2 \mu \mathrm{m}$ thick layer of Bi previously evaporated on stainless steel.

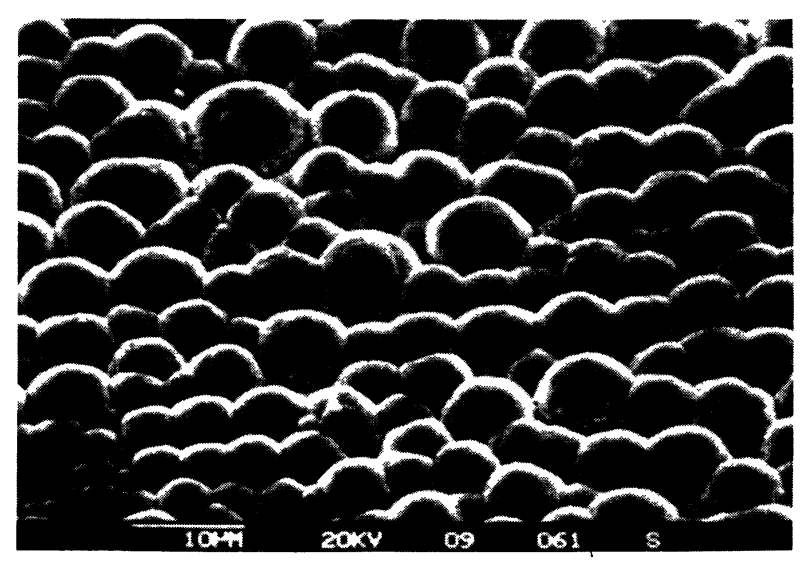

Fig. 4. - S.E.M. micrograph of a $1.5 \mu$ m thick $\mathrm{CuGa}_{0.5} \mathrm{In}_{0.5} \mathrm{Se}_{2}$ film grown at $250^{\circ} \mathrm{C}$ on a $2 \mu \mathrm{m}$ thick layer of Bi previously evaporated on stainless steel. deposited on the quasi-melted substrate is always one or two orders of magnitude less than that of the film deposited on the solid substrate. Considering that the number of carriers should be the same for the two films because they have been grown in the same conditions of doping with the same stoichiometry ratio, we attributed the difference in the resistivity of the two films to a much higher value of mobility in the film grown on the quasi-melted substrate in respect to that grown on the solid substrate. This is in agreement with the fact that the grain size is higher for films grown on quasi-melted substrates.

The values of resistivity measured for CdS, CdTe and $\mathrm{CuGaInSe}_{2}$ deposited on quasi-melted metals are as follows :

1) $1 \Omega . \mathrm{cm}$ for In-doped n-type CdS.

2) $10-100 \Omega . \mathrm{cm}$ for undoped p-type CdTe.

3) $1-10 \Omega . \mathrm{cm}$ for undoped p-type $\mathrm{CuGa}_{0.5} \mathrm{In}_{0.5} \mathrm{Se}_{2}$.

3. Interpretation. - The large grain growth on liquid substrates is justified by the fact that a liquid layer can give a high surface mobility to the adsorbed atoms and to the clusters as they are formed. The high cluster mobility favours both coalescence and orientation, giving rise to the large grain growth. According to the current theory of melting [8-12], the surface of a material can melt at a temperature much lower than its melting point.

Brougthton and Woodcock [8] report that the $(0,0,1)$ surface of a FCC crystal can melt at a temperature $30 \%$ lower than its bulk melting point, while the second layer, that is, the layer immediately under the surface, can melt at a temperature about $10 \%$ lower than the bulk melting point and the third layer melts close to the bulk melting temperature. Besides, the melting point of the surface depends on its packing density, being lower for the less packed surfaces and approaching the bulk melting point for the most packed surfaces [8]. Similar results have been reported by Pietronero and Tosatti [9] and experimental confirmations have been given by Heurion and Rhead [11] and Pavlovska and Nenow [12]. On the basis of the above-theory, we could explain our results by supposing that our metallic substrates, also if they are kept at a temperature lower than their melting point, exhibit a melted surface to the incoming molecules during the deposition. According to this interpretation, the growth on metals kept at a temperature lower than their melting points strictly resembles the rheotaxial growth. For this, Quasi-Rheotaxy preserves the advantages of Rheotaxy, which consist in the growth on very mobile surfaces, but it avoids the disadvantages of Rheotaxy, which consist in the formation of droplets. In conclusion, this new way of growing thin films, called Quasi-Rheotaxy, gives the possibility of obtaining large crystalline grain semiconductor thin films on amorphous low cost substrates, and could therefore give a substantial contribution to the realization of low cost thin film solar cells. 


\section{References}

[1] Hovel, H. J., Solar Cells, Semiconductors and Semimetals, (Academic Press, New York) 1975, vol. 11, p. 103.

[2] Soclof, S. and Iles, P. A., Extended Abstracts Electrochem. Soc. Fall Meeting, New York (1974) p. 618.

[3] Milnes, A. G. and Feucht, D. L., 12th IEEE Photovoltaic Specialists Conf., Baton Rouge, L. (1976) p. 997.

[4] Graef, M. W. H., Giling, L. J. and Bloem, J., J. Appl. Phys. 48 (1977) 3937.

[5] Romeo, N., Mat. Chem. 4 (1979) 571.

[6] Rombo, N., SBerveglieri, G. and TARricone, L., Thin Solid Films 55 (1979) 413.
[7] Nur Salad, A., Romeo, N., Sberveglieri, G., Vigil, O. and Zanotti, L., Mat. Chem. 4 (1979) 549.

[8] Broughton, J. Q. and WoodCock, L. V., J. Phys. C 11 (1978) 2743.

[9] Pietronero, L. and Tosatti, E., Solid State Commun. 32 (1979) 225.

[10] Matsubara, T., Iwase, Y. and Momokita, A., Progr. Theor. Phys. 58 (1977) 1102.

[11] Heurion, J. and Rhead, G. E., Surf. Sci. 29 (1972) 20.

[12] Pavlovska, A. and Nenow, D., Surf. Sci. 27 (1971) 211. 